\title{
Industrial Development Strategy and Stimulator Industry of Iran's Economy
}

\author{
Bijan Bidabad \\ B.A., M.Sc., Ph.D., Post Doc. \\ Professor of Economics and Chief Islamic Banking Advisor \\ Bank Melli Iran, Tehran, Iran \\ Email: bijan@bidabad.com
}

\begin{abstract}
With a glance on planning methodology, we try to analyze "Iran's industrial development strategy proposition". This proposition to somehow covers the requirements of Iran's economic development strategy, and in this regard can be treated as an economic strategy plan and not industrial strategy plan. Approaches of this proposition-ignoring its long-run quantitative forecasts- can be used as a general solution to Iran's long-run structural problems and can be summarized by international linkages and competitiveness as the main proposed strategies. But this proposition does not introduce stimulator engine sector of the economy; in this paper, we try to touch this nomination via an input-output sectoral linkages framework. We conclude that, to start of Iran's economic fast growth, sectors of glass and glassware, cement, mine, other mineral \& non-ferrous products, basic steel and iron mill products, paper \& wood industries, chemical \& plastic industries, copper $\&$ copper products, water and electricity in turn should be activated more to fulfill the needs for intermediate products in the economy. The sectors of foodstuff industries, aluminum, and other basic products of non-ferrous metals, copper and copper products, steel and iron mill products are able to increase the demand for intermediate products of other sectors more than the others. Basic steel and steel mill products, copper and copper products, aluminum and other basic non-ferrous metals products, cement, paper, and wood industries, glass and glassware, other mineral non-ferrous products, chemical industries, and plastic are more integrated than the others relating both forward and backward linkages. Machinery and equipment, basic products of steel and iron mill, chemical industries and plastic are mainly based on import and share of intermediate import to production of aluminum sectors and other basic products of non-ferrous metals, chemical industries, and plastic, basic steel and iron mill products, machinery and equipment industries is more than the other sectors. Aluminum and other basic products of non-ferrous metals, foodstuffs industries, basic products of steel and steel mill have a higher multiplier effect in increasing economy income, in other words, it is possible to consider them as pioneer sectors and economy stimulator engine. Aluminum and other basic products of nonferrous metals, foodstuff industries, basic products of steel and iron mill have more affect the growth of other sectors. Sectors of chemical and plastic industries, agriculture, transportation services, warehouse keeping and communications, commercial services provide the highest amount of input for other sectors. We consider two scenarios for Iran's industrial strategy as foodstuffs industries sector with export promotion, and the second, metals sectors (aluminum and other basic products of non-ferrous metals, basic products of steel and iron mill) with export promotion and import substitution.
\end{abstract}

Keywords: Industry, Development strategy, Iran, Input-output

\section{Introduction}

Before starting our discussion about performed researches in an industrial development strategy plan, we should take the chance to have a brief discussion about the methodology of designing a plan at different planning levels. At first, we should present that collection of mass information is not the solution insole for the problem of planning, and one of the faced problems in the way of economic, social, cultural development planning is the mass volume of information for such plans. On the other hand, in Iran's industrial development strategy, the methodology of processing such information was so weak and or even had not designed a priori, and finally, persons in charge should manage the plans in order to finalize it. This was also the case that we did not succeed within the four previous five years plans. The plans talked about their interests, and the economy and society and culture went toward their own directions and ways without regarding the approved plans! In territory management ${ }^{1}$ plans, we

I Bidabad, Bijan (2003), Teritory management methodology in teritory management of influence region of south Pars gas site, Genau Consulting Engineers, Oil Ministry, Iran, Tehran. 
had the same problems because, in this plan type, spatial information is added to other information and complicate planning method to conclude.

In theoretical classic planning style, we may have a country development strategy after determining the general goals and priorities of development as macro and long-run point of view. In other words, finding an industrial development strategy of the country is one of the classic planning stages that may use input from development priorities to determine the path to development goals and targets. Determining long-term quantitative goals are in the next step of the country's development strategy plan.

Basically, the country's development strategy includes different economic, social, cultural, military, political, international sectors which should be collected in one frame in order to provide the country's development strategy. The economic sector of development strategy includes some sub-sectors from which industrial development strategy is one of its sub-sectors. We present this sub-sector when this conjecture is close to reality that industry development with more emphasis on its growth should be accepted as a stimulator engine of the economy. Reaching such conjecture needs many analytical pre-requisites for answering this question of why the industry in one country should be considered as an economic development and growth engine. It is certainly impossible to answer this question without considering the general goals of economic development. If the goal is "economic growth", the answer is different from the case of defining the goal as "economic development". If the goal is a better distribution of income and wealth or is independence or welfare increase, different solutions are dictated, and basically, it is impossible to collect the goals altogether, because they may be conflictive from an executive point of view. For example, the fair distribution of income and wealth would be in conflict with economic growth goal of economy.

Another necessary consideration for designing industrial development strategy is the backward and forward inter-industrial linkages of different economic sectors which determine the position of sub-sectors in the economy as a whole. In other words, it is impossible to study industry as isolated or separated from the other sectors. It means we should consider the industry besides all other sectors. The growth of one sector, from forward and backward linkages points of views needs to the growth of other sectors. The basic question in finding the relevant industrial development strategy is this: by the growth of which sector we may have more growth in economic sectors? This is the basic question which may be raised in an industrial development strategy. The remaining analysis relative to this question could be considered as minor questions because the most important subject at this stage is to find the stimulator engine of the economy. In other words, we want to know how to lead country economic and political efforts toward some (unknown) activities in order to have a more powerful and productive economy. Therefore, it is after this stage that we may specify the quantitative long-run targets by considering sources and uses of different fields of wealth such as physical, financial, human, scientific, technological and then these targets may be divided into long-term, middle-term and short-term goals and detailed up to annual government budgets.

The research study: "industrial development strategy of Iran” considers different infrastructural policies which are necessary for country economic development as a whole. This proposition (industrial development strategy of Iran) by analyzing the process of economic and industrial changes in Iran and world, and by presenting two major specifications of economic closeness and wide ownership and interference of government and resulted monopolies, surveys Iran's economy and industrial development experience of the world countries. The presented idea in this regard is: if necessary major changes in modifying relevant sectors to industry and economy infrastructure could not occur, we will practically continue the current low productive process. One of the other aspects of the mentioned proposition is to draw a desirable future for Iran's industry. Desirable future of the industry from the point of view of this plan is based on inter-linkages with the foreign world and product competitiveness. Neglecting the proposition's quantitative predictions for next two decades which may be seriously affected by the concepts of scenario makers, the two above mentioned attitudes are the basic development problems in all other economic fields of the country. To obtain this viewpoint, political, economic, monetary, legal, financial, correction of the monopolistic infrastructure of government firms and agencies and different considerations about industries' size and technologic directives and production standards and competition in international realm are presented. Conclusion of the first part of "industrial development strategy" essentially is: economic-industrial development of Iran and obtaining a sustainable growth necessitates development of physical and human capitals, economic stability, productivity increase, dynamism and correction of production \& ownership infrastructure toward favor of private sector and encouragement of economic activities incentive on the base of profit earning, and creation of competition among domestic economic activities and creation of international competitiveness and outward looking and be 
placing in a better position of production and trade in international resources and work allocation system. It is necessary to confess that not only Iran's industrial development but also the only solution for Iranian economic development is the above items with some more or less consideration in the related fields. This plan (industrial development strategy plan) tries more to consider the strategies of industrial development fields, but the presented considerations and surveys do not suffice. In other words, this plan presents important general problems and obstacles of Iran economic development, but there is no answer to this question that which sector of industry or economy should be considered as the stimulator engine of the economy.

Certainly, the writers of that proposition tried to design it with a full understanding of the stylized fact that whenever general development of the country is reached, industry development may start. This approach is truly and thoroughly true, and the path of industrial growth passes through the legal, political, and economic reform of the country. Regarding all above-mentioned considerations, we may encounter the mentioned plan briefly as a development strategy than an industrial development strategy. The general strategic policies of this plan are summarized as international linkages and competitiveness, and the remained policies should follow these two guidelines. These strategic guidelines are acceptable in comparison to the development strategies of other countries. Generally, we may compare the following development strategies with the proposed "industrial development strategy of Iran".

\section{Economic strategies in temporary ages}

\begin{tabular}{ll}
\hline United States of America & Economic freedom, individualism, the profit incentive \\
\hline Japan & High-tech industries, productivity increase \\
\hline Southeastern Asia & Export of high-tech technology products \\
\hline Ex-Soviet Union & Limitations of non-capital imports and totalitarianism \\
\hline China & Labor intensive industries growth \\
\hline Europe & Renaissance, constraining religion, Think \& talk liberalization \\
\hline England & Colonization and exploitation of weak nations \\
\hline Western Europe & Industrial and technological development \\
\hline South-western Europe & Mercantilism \\
\hline Eastern Europe & Centralized Planned economics and self-dependency \\
\hline
\end{tabular}

Talking more about the analysis of that proposition would be tedious and out of our discussion scope. Here, we present an essential subject in relation to the industrial development strategy of Iran. In this paper, to improve industrial development strategy proposition along with accepting it as a good strategy for economic (and not industrial) development of country try to answer to this question: which economic sector(s) should be the leader(s) of economic activities and stimulator engine of Iran's economy. Before going through this discussion, we may consider all industrial linkages between economic sectors in the format of the input-output table.

\section{Input-Output table}

One of the most suitable tools to evaluate the relations and linkages among different sectors of the economy is the input-output table. This table can present a rather complete economic illustration of the country's economy. Along with complementing mathematical models, input-output tables can simulate economic policies. The input-output table, due to its limitations resulted from its structural assumptions, has extended reasoning abilities due to its linearity.

We assume that $f_{i}$ is final demand for produced products of sector $i$, and $X_{i}$ is the production of intermediate and final products 
of sector $\mathrm{i}$. Then

$$
a_{i j}=\frac{X_{i, j}}{X_{j}}
$$

Could be a sign of production need of sector $i$ for producing one unit of goods in sector $j$ as intermediate inputs. In this case, we may have:

$$
X_{i}=a_{i^{1}} X_{1}+a_{i^{2}} X_{2}+\ldots+a_{i n} X_{n}+f_{i} \quad i=1, \ldots, n
$$

In which, $a_{i j} X_{j}$ is the amount of produced products in sector $i$ for benefiting in sector $j$ as intermediate inputs. Total demand includes final demand $f_{i}$ and intermediate demand of $a_{i j} X_{j}$. We can rewrite the above relation in matrix notations as:

$$
\begin{aligned}
& X=A X+F \\
& 8 x I(8 x 8)(8 x I)(8 x I)
\end{aligned}
$$

By solving the above system of linear equations, we may have:

$$
\mathrm{X}=(\mathrm{I}-\mathrm{A})^{-1} \mathrm{~F}
$$

The matrix $\mathbf{A}$ and $(\mathbf{I}-\mathbf{A})^{-1}$ are named technical coefficients and Leontief inverse matrices. The matrix of technical coefficients (A) summarizes the total production of the economy into the inside and outside production processes of the economy's sectors and specify the internal content of transactions among different sectors. Direct effects are results of the direct production of goods in one sector. The indirect effects are those effects that may be created due to the production of one sector and upon secondary demands for products of other sectors of the economy. Therefore, by increasing the final demand in one sector, we may increase direct and indirect production and employment of all economic sectors. The elements of Leontief inverse show the direct and indirect effects on the production of sectors in case of any change in final demand. The elements of the latter matrix in comparison with the matrix of technical coefficients (A) may better analyze the linkages among different sectors of the economy.

\section{Analyzing the input-output table of Iran}

Iran Statistics Center supplied the latest input-output table for Iran's economy in I99I. This is a 78x78 sectors table, and its greatness may cause some increase in the volume of calculations and complicates the analysis, therefore, to make the analysis simpler and reducing additional calculations, we aggregated the table and mixed some sectors together and classified them under the title of the sector with more importance. In this regard, by using the pre-multiplication matrix, pre-aggregated matrix, and post-multiplication matrix, we obtained the aggregated matrix ${ }^{2}$. This latter matrix now is used for further analysis in this paper.

\section{Forward linkage index}

The forward linkage index for each sector is calculated by dividing the total final demand of sector by total intermediate demand of the sector. ${ }^{3}$ Therefore, we may have:

2 Bidabad, Bijan, Peyman Ghorbani (2002), Determining export markets for Iran's gas. Institute for energy studies, Iran, Tehran.

3 Esfandiari, A.S. (I986), Determining key economic sectors based on forward and backward linkeages, Plan and Budget Journal, No. 25, 26. pp.3-40. Iran, Tehran. 


\section{$F L=\frac{\text { Total final demand of sector }}{\text { Total intermediate demand of sector }} \times 100$}

This index shows the percentage of products of the considered sector as the intermediate demand of other sectors. Whatever the total products of one sector would be used in other sectors of the economy as intermediate products, the forward linkage index (FL) of that sector would be more, and it is possible to say that the growth of that sector would be more affected by the other sectors. In the table (I) we have calculated the forward linkage index of 22 sectors of Iran's economy, which have been reordered according to their FL indices for different economic sectors. The amount of forward indices reveals that if there is an increase of IOO Rials in final demand of the economy, there will be an increase in the considered sector for FL Rials. In other words, the $\%$ FL of products of the mentioned sector would be used as an intermediate input in other economic sectors.

Table I- Forward linkage index of different sectors of Iran's economy

\begin{tabular}{|c|c|c|c|}
\hline Grade & FL Index & Sector no. & Name of sector \\
\hline $\mathrm{I}$ & 89.8 & 8 & Glass \& glassware \\
\hline 2 & 86.0 & 7 & Cement \\
\hline 3 & 84.6 & 3 & Mine \\
\hline 4 & 84.3 & 9 & Other non-metallic mineral products \\
\hline 5 & 83.7 & $\mathrm{I} 2$ & Basic products of steel \& iron mill \\
\hline 6 & 82.6 & $\mathrm{I} 2$ & Paper $\&$ wood industries \\
\hline 7 & 74.5 & II & Chemicals industries \& plastic \\
\hline 8 & 72.5 & 16 & Copper \& Copper products \\
\hline 9 & $7 \mathrm{I} .5$ & 16 & Water \& electricity \\
\hline I0 & 68.2 & $2 \mathrm{I}$ & Services of financial institutes, bank \& insurance \\
\hline II & 66.4 & 6 & Wood industries \\
\hline 12 & 65.5 & $\mathrm{I} 4$ & Aluminum $\&$ other non-ferrous metals basic products \\
\hline $\mathrm{I3}$ & 65.1 & $\mathrm{I}$ & Agriculture \\
\hline $\mathrm{I} 4$ & 47.7 & 20 & Transportation services, warehouse keeping \& communications \\
\hline I5 & 34.1 & I7 & Natural gas \\
\hline 16 & 28.9 & 10 & Textile industries \& leather \\
\hline 17 & 25.2 & 15 & Machinery industries \& equipment \\
\hline 18 & 20.7 & 19 & Commercial services \\
\hline I9 & 19.2 & 4 & Foodstuffs industries \\
\hline 20 & 8.5 & 18 & Building \\
\hline $2 \mathrm{I}$ & 4.6 & 22 & Other services \\
\hline 22 & 2.4 & 2 & Crude oil \& natural gas \\
\hline \multicolumn{3}{|c|}{53.9} & Average of sectors \\
\hline
\end{tabular}

\section{Backward linkage}

The backward linkage index for each sector would be calculated from the total intermediate costs of each sector divided by the total output of the sector.

$$
F L=\frac{\text { Total intermediate cost of sector }}{\text { Total final demand of sector }} \times 100
$$

This index shows the dependency of each sector to other sectors and reveals that the considered sector may consume how much products of another sector as intermediate inputs. By use of 22 sectors input-output table, we have calculated this index for all 22 sectors and are depicted at the table (2). According to this table, we have foodstuffs industries at the first level and crude oil and natural gas at the lowest level. 
Table 2- Backward linkage Index of different sectors of Iran's economy

\begin{tabular}{|c|c|c|c|}
\hline Grade & BL index & Sector no. & Name of sector \\
\hline $\mathrm{I}$ & 79.8 & 4 & Foodstuffs industries \\
\hline 2 & 71.3 & $\mathrm{I} 4$ & Aluminum $\&$ other non-ferrous metals basic products \\
\hline 3 & 66.3 & $\mathrm{I} 3$ & Copper \& Copper products \\
\hline 4 & 63.3 & 12 & Basic products of steel and iron mill \\
\hline 5 & 55.3 & 6 & Wood industries \\
\hline 6 & 55.1 & 10 & Textile industries \& leather \\
\hline 7 & 52.1 & II & Chemical industries $\&$ plastic \\
\hline 8 & 50.2 & 7 & Cement \\
\hline 9 & 50.2 & 5 & Paper \& wood \\
\hline 10 & 49.4 & 18 & Building \\
\hline II & 48.3 & I5 & Machinery industries \& equipment \\
\hline 12 & 45.6 & 9 & Other mineral non-ferrous products \\
\hline I3 & 42.6 & 8 & Glass \& glassware \\
\hline I4 & 39.0 & 16 & Water \& electricity \\
\hline 15 & 34.3 & I & Agriculture \\
\hline 16 & 33.1 & 20 & Transportation services, warehouse keeping $\&$ communications \\
\hline 17 & 31.0 & 17 & Natural gas \\
\hline 18 & 29.3 & $2 \mathrm{I}$ & Financial institutes services, bank $\&$ insurance \\
\hline 19 & 21.7 & 22 & Other services \\
\hline 20 & 19.3 & 3 & Mine \\
\hline $2 \mathrm{I}$ & II.5 & 19 & Commercial services \\
\hline 22 & 3.2 & 2 & Crude oil \& natural gas \\
\hline \multicolumn{3}{|r|}{43.3} & Average of sectors \\
\hline
\end{tabular}

\section{Integration index}

Forward and Backward indices are complementary. In order to obtain a correct estimation of linkage (integration) index of one sector in the economic transaction with the economy, we may benefit from the average of two indexes.

$$
D B F L=\frac{B L+F L}{2}
$$

Where, DBFL is the integration coefficient.

According to the forward and backward indices, we can calculate the integration index for different sectors as depicted by table (3). As it is obvious, basic products of steel and iron mills is at the top of the table and Crude oil and natural gas in the bottom.

Table 3- Integration Index of different sectors of Iran's economy

\begin{tabular}{cccl}
\hline Grade & $\begin{array}{l}\text { Integration } \\
\text { index }\end{array}$ & $\begin{array}{l}\text { Sector } \\
\text { no. }\end{array}$ & Name of sector \\
\hline I & 73.7 & I2 & Basic products of steel \& iron mill \\
\hline 2 & 69.4 & I3 & Copper \& copper products \\
\hline 3 & 68.4 & I4 & Aluminum \& other non-ferrous metals basic products \\
\hline 4 & 68.1 & 7 & Cement \\
\hline
\end{tabular}




\begin{tabular}{|c|c|c|c|}
\hline 5 & 66.4 & 5 & Paper \& Wood industries \\
\hline 6 & 66.2 & 8 & Glass \& Glassware \\
\hline 7 & 64.9 & 9 & Other mineral non-ferrous products \\
\hline 8 & 63.3 & II & Chemical \& plastic industries \\
\hline 9 & 60.8 & 6 & Wood industries \\
\hline 10 & 55.2 & 16 & Water \& Electricity \\
\hline II & 51.9 & 3 & Mine \\
\hline 12 & 49.7 & $\mathrm{I}$ & Agriculture \\
\hline $\mathrm{I} 3$ & 49.5 & 4 & Foodstuffs industries \\
\hline 14 & 48.7 & $2 \mathrm{I}$ & Financial institutes services, bank, and insurance \\
\hline 15 & 42.0 & 10 & Textile \& leather industries \\
\hline 16 & 40.4 & 20 & Transportation services, warehouse keeping \& communications \\
\hline 17 & 36.7 & I5 & Machinery \& equipment industries \\
\hline 18 & 32.6 & 17 & Natural gas \\
\hline 19 & 28.9 & I8 & Building \\
\hline 20 & I6.I & 19 & Commercial services \\
\hline $2 \mathrm{I}$ & 13.2 & 22 & Other services \\
\hline 22 & 2.8 & 2 & Crude oil \& natural gas \\
\hline \multicolumn{3}{|c|}{48.6} & Average of sectors \\
\hline
\end{tabular}

\section{Index of direct import intensity}

This index shows the ratio of import of each sector to the production value of the same sector. By this index, we may find the import percentage of one sector. For calculation of this index the following formula may be used:

$$
\text { Direct import intensity of } \mathrm{j}^{\text {th }} \text { sector }=\frac{\text { Import of } \mathrm{j}^{\text {th }} \text { sector }}{\text { Production of } \mathrm{j}^{\text {th }} \text { sector }} \times 100
$$

As it is obvious from the table (4), direct import intensity of machinery and equipment with an index of \% I.39 is at the first level, and building sector with an index near to zero is at the bottom of the table. Of course, in contrast with previous indices, any lower value for this index may be interpreted as more self-sufficiency of that sector.

Table 4- Direct import intensity Index of different sectors of Iran's industry

\begin{tabular}{|c|c|c|c|}
\hline Grade & $\begin{array}{l}\text { Direct import } \\
\text { intensity index }\end{array}$ & Sector no. & Name of sector \\
\hline $\bar{I}$ & $\mathrm{I} .3$ & $\mathrm{I5}$ & Machinery industries \& equipment \\
\hline 2 & 1.2 & $\mathrm{I} 2$ & Basic products of steel and iron mill \\
\hline 3 & 1.0 & II & Chemical industries and plastic \\
\hline 4 & 0.4 & I4 & Aluminum \& other non-ferrous metals basic products \\
\hline 5 & 0.4 & 5 & Paper \& wood industries \\
\hline 6 & 0.3 & 8 & Glass \& glassware \\
\hline 7 & O.I & 6 & Wood industries \\
\hline
\end{tabular}




\begin{tabular}{|c|c|c|c|}
\hline 8 & O.I & 10 & Textile \& leather industries \\
\hline 9 & O.I & I3 & Copper \& copper products \\
\hline $\mathrm{IO}$ & 0.1 & 3 & Mine \\
\hline II & 0.0904 & $2 \mathrm{I}$ & Financial institutes services, bank, and insurance \\
\hline $\mathrm{I} 2$ & 0.0722 & 4 & Foodstuffs industries \\
\hline $\mathrm{I3}$ & 0.0582 & 20 & Transportation services, warehouse keeping, and communications \\
\hline $\mathrm{I} 4$ & 0.0484 & 9 & Other mineral non-ferrous products \\
\hline I5 & $0.04 \mathrm{I} 4$ & 7 & Cement \\
\hline 16 & 0.0242 & $\mathrm{I}$ & Agriculture \\
\hline 17 & 0.0192 & I9 & Commercial services \\
\hline I8 & 0.0014 & 22 & Other services \\
\hline I9 & 0.0000 & 2 & Crude oil \& natural gas \\
\hline 20 & 0.0000 & 16 & Water \& electricity \\
\hline $2 \mathrm{I}$ & 0.0000 & I7 & Natural gas \\
\hline 22 & 0.0000 & I8 & Building \\
\hline \multicolumn{3}{|c|}{0.2701} & Average of sectors \\
\hline
\end{tabular}

\section{Index of intermediate import intensity}

This index shows the ratio of intermediate import of each sector to the production value of the same sector. By this index, we may find the intermediate import percentage of a sector. On the other hand, when this index is high, the related sector is more dependent on foreign economies in producing final and intermediate products. For calculation of this index the following formula may be used:

\section{Intermediate import intensity of $\mathrm{j}^{\text {th }}$ sector $=\frac{\text { Intermediate import of } \mathrm{j}^{\text {th }} \text { sector }}{\text { Production of } \mathrm{j}^{\text {th }} \text { sector }} \times 100$}

Table (5) presents this index for 22 sectors. From the viewpoint of intermediate import intensity index, aluminum and other non-ferrous metals is the first and crude oil and natural gas in the last one.

Table 5- Intermediate import intensity index of Iran's industry

\begin{tabular}{cccl}
\hline Grade & $\begin{array}{l}\text { Intermediate import } \\
\text { intensity index }\end{array}$ & Sector no. & Name of sector \\
\hline I & 27.5 & I4 & Aluminum \& other non-ferrous metals basic products \\
\hline 2 & I7.75 & I & Chemical industries and plastic \\
\hline 3 & I7.0I & I2 & Basic products of steel \& iron mill \\
\hline 4 & I5.7 & I5 & Machinery industries \& equipment \\
\hline
\end{tabular}




\begin{tabular}{lccl}
\hline 5 & I3.84 & I8 & Building \\
\hline 6 & II.79 & 2 I & Financial institutes services, bank, and insurance \\
\hline 7 & I0.12 & 5 & Paper \& wood industries \\
\hline 8 & 9.89 & 20 & Transportation services, warehouse keeping, and communications \\
\hline I0 & 9.65 & 6 & Wood industries \\
\hline II & 9.53 & I3 & Copper \& copper products \\
\hline I2 & 8.97 & I0 & Textile \& leather industries \\
\hline I3 & 5.08 & I7 & Natural gas \\
\hline I4 & 5.05 & I6 & Water \& electricity \\
\hline I5 & 4.68 & 9 & Other mineral non-ferrous products \\
\hline I6 & 4.33 & 22 & Other services \\
\hline I7 & 4.26 & 8 & Glass \& glassware \\
\hline I8 & 4.14 & 4 & Foodstuffs industries \\
\hline I9 & 3.99 & I & Agriculture \\
\hline 20 & 2.3 & 3 & Mine \\
\hline 21 & 1.22 & I9 & Commercial services \\
\hline 22 & 0.56 & 7 & Cement \\
\hline & 0.26 & 2 & Crude oil \& natural gas \\
\hline & & & Average of sectors \\
\hline
\end{tabular}

\section{Multiplier index}

Multiplier coefficient also reveals the position of a sector in the country economy and in relation with other sectors. This index is calculated from the column sums of Leontief inverse $(\mathbf{I}-\mathbf{A})^{-1}$. Since Leontief inverse shows the direct and indirect linkages of economic sectors, the element of the $i^{\text {th }}$ row and $j^{\text {th }}$ column in this matrix reveals the value of direct and indirect inputs required from the $i^{\text {th }}$ sector for producing one unit of products in sector $j$. The columns sums of this matrix reveal the total effect of the increase of one unit production of the corresponding sector on other economic sectors. When multiplier index is high, the corresponding sector is more income generator in the economy than the other sectors. It means that we may consider that sector as stimulator engine of the economy.

Table (6) reveals the multiplier for 22 Iran's sectors. As it is obvious, the highest coefficient belongs to aluminum and other non-ferrous metals basic products. That is one unit increase of final demand in this sector, will increase the total production of the economy by 2.52 units. The lowest amount of this index belongs to crude oil and natural gas. Whatever the needs and linkages of one sector to the intermediate outputs of other sectors is higher; its multiplier is also higher.

Table 6- Multiplier of different sectors of Iran's industry

\begin{tabular}{|c|c|c|c|}
\hline Grade & Multiplier & $\begin{array}{l}\text { Sector } \\
\text { no. }\end{array}$ & Name of sector \\
\hline $\mathrm{I}$ & $2.5 \mathrm{I}$ & $\mathrm{I} 4$ & Aluminum $\&$ other non-ferrous metals basic products \\
\hline 2 & 2.30 & 4 & Foodstuffs industries \\
\hline 3 & $2 . \mathrm{I} 4$ & 12 & Basic products of steel \& iron mill \\
\hline 4 & 1.99 & 13 & Copper \& copper products \\
\hline 5 & 1.98 & 10 & Textile $\&$ leather industries \\
\hline 6 & 1.92 & 6 & Wood industries \\
\hline 7 & I.9I & 18 & Building \\
\hline 8 & 1.89 & I5 & Machinery industries \& equipment \\
\hline 9 & 1.85 & II & Chemical industries \& plastic \\
\hline
\end{tabular}




\begin{tabular}{|c|c|c|c|}
\hline $\mathrm{IO}$ & $\mathrm{I} .8 \mathrm{I}$ & 5 & Paper \& wood industries \\
\hline II & 1.75 & 7 & Cement \\
\hline 12 & 1.72 & 9 & Other mineral non-ferrous products \\
\hline $\mathrm{I3}$ & 1.67 & 8 & Glass \& glassware \\
\hline $\mathrm{I} 4$ & 1.63 & 16 & Water \& electricity \\
\hline I5 & 1.56 & $\mathrm{I}$ & Agriculture \\
\hline 16 & 1.53 & 20 & Transportation services, warehouse keeping, and communications \\
\hline I7 & 1.47 & $2 \mathrm{I}$ & Financial institutes services, bank, and insurance \\
\hline 18 & 1.47 & 17 & Natural gas \\
\hline I9 & 1.39 & 22 & Other services \\
\hline 20 & 1.30 & 3 & Mine \\
\hline $2 \mathrm{I}$ & 1.20 & 19 & Commercial services \\
\hline 22 & 1.05 & 2 & Crude oil \& Natural gas \\
\hline \multicolumn{3}{|c|}{1.73} & Average of sectors \\
\hline
\end{tabular}

\section{Dispersion power index}

This index measures the power of dispersion of increasing one unit of final demand of a sector on the production of other sectors. Higher dispersion index means that the considered sector will more affect the growth of other sectors. This index is defined as follows:

$$
P=\frac{n \sum_{j=1}^{n} b_{i j}}{\sum_{i=1}^{n} \sum_{j=1}^{n} b_{i j}}=\frac{n \times \text { sum of } i^{\text {th }} \text { row of Leontief inverse }}{\text { sum of all elements of Leontief inverse }}
$$

Where $b_{i j}$ is the elements of Leontief inverse and $n$ is the number of sectors. This index is also named as normal forward linkage index, which is the result of dividing the average coefficient of sector $j: \frac{1}{n} \sum_{j=1}^{n} b_{i j}$ by the total economy average of $\frac{1}{n^{2}}\left(\sum_{i=1}^{n} \sum_{j=1}^{n} b_{i j}\right)$. If $\mathrm{P}$ is higher than $\mathrm{I}$, then the effects of that sector on other sectors is greater than the average of the economy and conversely, when $\mathrm{p}$ is less than $\mathrm{I}$, then means the effectiveness of this sector is less than the average of econ omic sectors. Table (7) shows the amounts of this index. From this point of view, aluminum and other basic products of non-ferrous metals is at the top, and the crude oil and natural gas is at the bottom of the ranking.

Table 7- Dispersion power index of different sectors of Iran's industry

\begin{tabular}{cccl}
\hline Grade & Distribution index & Sector no. & Name of sector \\
\hline I & I.45 & I4 & Aluminum and other non-ferrous metals basic products \\
\hline 2 & 1.32 & 4 & Foodstuffs industries \\
\hline 3 & I.23 & I2 & Basic products of steel \& iron mill \\
\hline 4 & I.I4 & I3 & Copper \& copper products \\
\hline 5 & I.I4 & I0 & Textile \& leather industries \\
\hline 6 & I.I0 & 6 & Wood industries \\
\hline 7 & I.I0 & I8 & Building \\
\hline
\end{tabular}




\begin{tabular}{|c|c|c|c|}
\hline 8 & 1.09 & I5 & Machinery industries \& equipment \\
\hline 9 & 1.06 & II & Chemical industries \& plastic \\
\hline $\mathrm{IO}$ & I.0I & 5 & Paper \& wood industries \\
\hline I I & $\mathrm{I} .0 \mathrm{I}$ & 7 & Cement \\
\hline 12 & 0.99 & 9 & Other mineral non-ferrous products \\
\hline $\mathrm{I3}$ & 0.96 & 8 & Glass \& glassware \\
\hline $\mathrm{I} 4$ & 0.94 & 16 & Water \& electricity \\
\hline I5 & 0.90 & $\mathrm{I}$ & Agriculture \\
\hline 16 & 0.88 & 20 & Transportation services, warehouse keeping, and communications \\
\hline 17 & 0.85 & $2 \mathrm{I}$ & Financial institutes services, bank, and insurance \\
\hline I8 & 0.84 & 17 & Natural gas \\
\hline I9 & 0.80 & 22 & Other services \\
\hline 20 & 0.75 & 3 & Mine \\
\hline $2 \mathrm{I}$ & 0.69 & 19 & Commercial services \\
\hline 22 & 0.60 & 2 & Crude oil \& Natural gas \\
\hline \multicolumn{3}{|c|}{1.00} & Average of sectors \\
\hline
\end{tabular}

\section{Index of sensitivity}

The sensitivity index is a complement to the dispersion power index. More production of input by one sector for other sectors causes the former a sensitive sector and its sensitivity index will be higher. This index is calculated by the following formula:

$$
q=\frac{n \sum_{i=1}^{n} b_{i j}}{\sum_{i=1}^{n} \sum_{j=1}^{n} b_{i j}}=\frac{n \times \text { sum of } j^{\text {th }} \text { column of Leontief inverse }}{\text { sum of all elements of Leontief inverse }}
$$

Where $b_{i j}$ is the elements of Leontief inverse and $n$ is the number of sectors. This index is also named as normal backward linkage index which is derived by dividing the average coefficients of sector $\mathrm{j}, \frac{1}{n} \sum_{i=1}^{n} b_{i j}$ by total economy coefficients of $\frac{1}{n^{2}}\left(\sum_{i=1}^{n} \sum_{j=1}^{n} b_{i j}\right)$. If the sensitivity index is high, it means the effectiveness of this sector from the other sector's growth is

higher than the growth of the others. That is, it means the growth of other sectors force this sector to grow; because, this sector should produce and fulfill the demands of other sectors for intermediate inputs. A sector with high sensitivity index means that it is a basic sector, and any lack of attention to that sector may result in bottlenecks in the growth of other sectors. This is because this sector should supply the intermediate inputs of other sectors in the production process and in case of its passive growth; there would be a shortage in supply of required intermediate inputs for other sectors.

Table (8) shows the sensitivity indices for different sectors of Iran's economy. As it is obvious, chemical \& rubber industries are at the top and cement is at the bottom of the list. According to the dispersion power index (primary effects, either direct or indirect) and sensitivity index (secondary effects), we may specify the priority of different sectors. It is obvious that those sectors with high $\mathrm{P}$ and $\mathrm{Q}$ may have a higher position and ability in the internalization of the production system and production process. 
Table 8- Sensitivity index of different sectors of Iran's industry

\begin{tabular}{cccl}
\hline Grade & $\begin{array}{l}\text { Sensitivity } \\
\text { index }\end{array}$ & $\begin{array}{l}\text { Sector } \\
\text { no. }\end{array}$ & Name of sector \\
\hline I & I.73 & II & Chemical industries \& plastic \\
\hline 2 & I.65 & I & Agriculture \\
\hline 3 & I.53 & 20 & Transportation services, warehouse keeping, and communications \\
\hline 4 & I.47 & I9 & Commercial services \\
\hline 5 & I.24 & I2 & Basic products of steel and iron mill \\
\hline 6 & I.22 & 3 & Mine \\
\hline 7 & I.13 & I5 & Machinery industries \& equipment \\
\hline 8 & I.I2 & I4 & Aluminum \& other non-ferrous metals basic products \\
\hline 9 & I.02 & I6 & Water \& Electricity \\
\hline I0 & I.00 & 22 & Other services \\
\hline I I & 0.91 & I0 & Textile leather industries \\
\hline I2 & 0.91 & 5 & Paper \& wood industries \\
\hline I3 & 0.80 & 4 & Foodstuffs industries \\
\hline I4 & 0.79 & 21 & Financial institutes services, bank, and insurance \\
\hline I5 & 0.74 & 9 & Other mineral non-ferrous products \\
\hline I6 & 0.69 & I3 & Copper \& copper products \\
\hline I7 & 0.69 & 2 & Crude oil \& natural gas \\
\hline I8 & 0.68 & 8 & Glass \& glassware \\
\hline I9 & 0.68 & I8 & Building \\
\hline 20 & 0.67 & 6 & Wood industries \\
\hline 21 & 0.65 & I7 & Natural gas \\
\hline 22 & 0.60 & 7 & Cement \\
\hline & 1.0000 & Average of sectors \\
\hline
\end{tabular}

Variability indices (coefficient of variation)

Normal forward (dispersion) and normal backward (sensitivity) indices may be greater than I, but the linkages may be through few sectors' linkages and strong linkages are by only a few sectors. In other words, normal backward or forward linkages may be relatively unequal among sectors. The following indices are presented to remove this shortage. The forward coefficient of variation or normal forward linkage is:

$F V_{i}=\sqrt{\frac{\frac{1}{n-1} \sum_{j=1}^{n}\left(b_{i j}-\frac{1}{n} \sum_{j=1}^{n} b_{i j}\right)}{\frac{1}{n} \sum_{j=1}^{n} b_{i j}}}$

The backward coefficient of variation or normal backward linkage is:

$$
B V_{i}=\sqrt{\frac{\frac{1}{n-1} \sum_{i=1}^{n}\left(b_{i j}-\frac{1}{n} \sum_{i=1}^{n} b_{i j}\right)}{\frac{1}{n} \sum_{i=1}^{n} b_{i j}}}
$$


Now, by dividing these indices by their means, the forward spread index is created as:

$$
F S_{i}=\frac{F V_{i}}{\overline{F V}}=\frac{F V_{i}}{\frac{1}{n} \sum_{i=1}^{n} F V_{i}}
$$

And backward spread index as:

$$
B S_{j}=\frac{B V_{j}}{\overline{B V}}=\frac{B V_{j}}{\frac{1}{n} \sum_{j=1}^{n} B V_{j}}
$$

\begin{tabular}{|c|c|c|c|}
\hline Grade & $\begin{array}{l}\text { Diffusion } \\
\text { index }\end{array}$ & $\begin{array}{l}\text { Sector } \\
\text { no. }\end{array}$ & Name of sector \\
\hline 23 & 0.6638 & 19 & Commercial services \\
\hline 24 & 0.7333 & 20 & Transportation services, warehouse keeping, and communications \\
\hline 25 & 0.8128 & 3 & Mine \\
\hline 26 & 0.8170 & II & Chemical industries $\&$ plastic \\
\hline 27 & 0.8193 & 22 & Other services \\
\hline 28 & 0.8808 & 15 & Machinery industries $\&$ equipment \\
\hline 29 & 0.9523 & 16 & Water \& Electricity \\
\hline 30 & 0.9892 & 9 & Other mineral non-ferrous products \\
\hline $3 \mathrm{I}$ & 0.9942 & 2 & Crude oil \& natural gas \\
\hline 32 & 0.9959 & $\mathrm{I}$ & Agriculture \\
\hline 33 & 1.0053 & 18 & Building \\
\hline 34 & 1.0280 & 17 & Natural gas \\
\hline 35 & 1.0389 & 4 & Foodstuffs industries \\
\hline 36 & 1.0567 & $2 \mathrm{I}$ & Financial institutes services, bank, and insurance \\
\hline 37 & $1.07 \mathrm{I} 4$ & 5 & Paper \& wood industries \\
\hline 38 & 1.0725 & 7 & Cement \\
\hline 39 & 1.0934 & $\mathrm{I} 2$ & Basic steel products $\&$ iron mill \\
\hline 40 & 1.0982 & 8 & Glass \& glassware \\
\hline $4 \mathrm{I}$ & I.II67 & 6 & Wood industries \\
\hline 42 & I.I465 & $\mathrm{I3}$ & Copper \& copper products \\
\hline 43 & I.2065 & I0 & Textile \& leather industries \\
\hline \multirow[t]{2}{*}{44} & 1.4066 & $\mathrm{I} 4$ & Aluminum $\&$ other non-ferrous metals basic products \\
\hline & 1.0000 & & The average of sectors \\
\hline
\end{tabular}

Table 9- Forward spread index of different sectors of Iran's industry

Lower backward and forward spread indices mean that sector has more consolidate relations with backward and forward sectors. Tables (9) and (I0) show these indices for 22 sectors with an order from higher to lower.

From the point of view of backward spread index, aluminum and other basic products of non-ferrous metals has the most amount, and commercial services has the lowest amount. If BS is lower than I, it is signing that the linkages of this sector with other sectors have been distributed equally and in contrast, if it is higher than $I$, it is signing that the linkage of this sector comes from linkage to only a few other sectors.

As it is obvious from the backward diffusion index table that aluminum and other basic non-ferrous metal products has the highest backward spread index and the building has the lowest spread index. If FS is lower than I, it means that the backward 
linkages of the considered sector have been distributed equally (in comparison with other sectors) and if FS is higher than I, it is a sign of linkages with few other sectors.

Totally, if $\mathrm{P}$ index is greater than or equal to I and BS index is lower than I, then the corresponding sector is a key sector from a backward linkage point of view. Also, if $\mathrm{q}$ index is greater than or equal to I, and FS is lower than I, then the corresponding sector is an important and key sector from forward linkages point of view. (Bulmer I982)

Table I0- Backward spread index of different sectors of Iran's industry

\begin{tabular}{|c|c|c|c|}
\hline Grade & $\begin{array}{l}\text { Backward } \\
\text { diffusion } \\
\text { index }\end{array}$ & $\begin{array}{l}\text { Sector } \\
\text { no. }\end{array}$ & Name of sector \\
\hline $\mathrm{I}$ & $0.805 \mathrm{I}$ & 18 & Building \\
\hline 2 & 0.8340 & 7 & Cement \\
\hline 3 & 0.8593 & 9 & Other mineral non-ferrous products \\
\hline 4 & 0.9017 & 6 & Wood industries \\
\hline 5 & 0.9085 & 17 & Natural gas \\
\hline 6 & 0.9247 & 15 & Machinery industries \& equipment \\
\hline 7 & $0.928 \mathrm{I}$ & 8 & Glass \& glassware \\
\hline 8 & 0.9484 & 22 & Other services \\
\hline 9 & 0.9532 & 13 & Copper \& copper products \\
\hline 10 & 0.9758 & 3 & Mines \\
\hline II & $1.004 \mathrm{I}$ & 4 & Foodstuffs industries \\
\hline $\mathrm{I} 2$ & 1.0145 & 16 & Water \& electricity \\
\hline $\mathrm{I3}$ & 1.0192 & 5 & Paper $\&$ wood industries \\
\hline $\mathrm{I} 4$ & 1.0285 & 20 & Transportation services, warehouse keeping, and communications \\
\hline 15 & 1.0307 & 19 & Commercial services \\
\hline 16 & 1.0387 & $2 \mathrm{I}$ & Financial institutes services, bank, and insurance \\
\hline 17 & 1.0864 & 2 & Crude oil \& natural gas \\
\hline 18 & 1.0903 & 10 & Textile \& leather industries \\
\hline 19 & I.1025 & II & Chemical industries \& plastic \\
\hline 20 & I.1062 & 12 & Basic steel products $\&$ iron mill \\
\hline $2 \mathrm{I}$ & I.I864 & $\mathrm{I}$ & Agriculture \\
\hline \multirow[t]{2}{*}{22} & 1.2538 & $\mathrm{I} 4$ & Aluminum \& other basic products of non-ferrous metals \\
\hline & 1.0000 & & Average of sectors \\
\hline
\end{tabular}

The omission of import from dispersion and sensitivity indices

As mentioned earlier, operationally, the dispersion and sensitivity indices are used to determine the key sectors. But it may be distorted by the existence of the role of imports; because the calculated indices are affected by the amount of intermediate imports. In this case, the establishment of linkages may due to sectors' needs of intermediate imports. Therefore, it will be better to calculate the dispersion and sensitivity indices after omitting the effects of imports from Leontief inverse by use of domestic Leontief inverse matrix of $\left(\mathbf{I}-A_{d}\right)^{-1}$.

Tables (II) and (I2) show the dispersion and sensitivity indices according to domestic Leontief inverse. To obtain domestic Leontief inverse, we deduct the intermediate imports matrix from the first area matrix of the input-output table and then calculate $\left(\mathrm{I}-\mathrm{Ad}_{\mathrm{d}}\right)^{-1}$.

As it is obvious, after omitting the import effects, the foodstuffs industries have higher dispersion index than the other sectors, and crude oil and natural gas has the lowest value. Also, after omitting the effect of imports from the sensitivity index of 
different sectors, the agriculture sector has the first rank, and cement sector has the last rank. Before omitting the import effect, we had agriculture sector in second and cement in the last ranks.

Table II - Dispersion index after omission of import effect

\begin{tabular}{|c|c|c|c|}
\hline Grade & $\begin{array}{c}\text { Dispersion } \\
\text { index }\end{array}$ & $\begin{array}{c}\text { Sector } \\
\text { no. }\end{array}$ & Name of sector \\
\hline $\mathrm{I}$ & 1.42 & 4 & Foodstuffs industries \\
\hline 2 & I.I6 & 13 & Copper \& copper products \\
\hline 3 & I.I4 & 10 & Textile \& leather industries \\
\hline 4 & I.I2 & $\mathrm{I} 2$ & Basic products of steel \& iron mill \\
\hline 5 & I.II & 7 & Cement \\
\hline 6 & I.I I & 6 & Wood industries \\
\hline 7 & 1.09 & 14 & Aluminum \& other non-ferrous metals basic products \\
\hline 8 & 1.05 & 9 & Other mineral non-ferrous products \\
\hline 9 & 1.04 & 5 & Paper \& wood industries \\
\hline 10 & 1.03 & 8 & Glass \& glassware \\
\hline II & 1.02 & 18 & Building \\
\hline $\mathrm{I2}$ & 0.99 & 16 & Water \& electricity \\
\hline 13 & 0.98 & I5 & Machinery \& equipment industries \\
\hline $\mathrm{I} 4$ & 0.97 & II & Chemical industries \& plastic \\
\hline 15 & 0.96 & $\mathrm{I}$ & Agriculture \\
\hline 16 & 0.89 & 17 & Natural gas \\
\hline 17 & 0.87 & 20 & Transportation services, warehouse keeping, and communications \\
\hline 18 & 0.84 & 22 & Other services \\
\hline 19 & 0.83 & $2 \mathrm{I}$ & Financial institutes services, bank, and insurance \\
\hline 20 & 0.82 & 3 & Mine \\
\hline $2 \mathrm{I}$ & 0.77 & 19 & Commercial services \\
\hline \multirow[t]{2}{*}{22} & 0.69 & 2 & Crude oil \& natural gas \\
\hline & 1.0000 & & Average of sectors \\
\hline
\end{tabular}

Table I2- Sensitivity index after omission of import effect

\begin{tabular}{cccl}
\hline Grade & $\begin{array}{c}\text { Sensitivity } \\
\text { index }\end{array}$ & $\begin{array}{c}\text { Sector } \\
\text { no. }\end{array}$ & \multicolumn{1}{l}{ Name of sector } \\
\hline I & I.8I & I & Agriculture \\
\hline 2 & I.55 & 20 & Transportation services, warehouse keeping, and communications \\
\hline 3 & I.52 & I9 & Commercial services \\
\hline 4 & I.38 & 3 & Mine \\
\hline 5 & I.I7 & I I & Chemical industries \& plastic \\
\hline 6 & I.12 & I6 & Water \& electricity \\
\hline 7 & I.08 & 22 & Other services \\
\hline 8 & 0.98 & I5 & Machinery \& equipment industries \\
\hline 9 & 0.98 & I0 & Textile \& leather industries \\
\hline I0 & I.94 & I2 & Basic products of steel \& iron mill \\
\hline I I & I.88 & 4 & Foodstuffs industries \\
\hline I2 & 0.88 & 5 & Paper \& wood industries \\
\hline I3 & 0.86 & I4 & Aluminum \& other non-ferrous metals basic products \\
\hline I4 & 0.84 & 9 & Other mineral non-ferrous products \\
\hline I5 & 0.81 & 2 I & Financial institutes services, bank, and insurance \\
\hline
\end{tabular}




\begin{tabular}{llcl}
\hline I6 & 0.77 & I8 & Building \\
\hline I7 & 0.76 & 2 & Crude oil \& natural gas \\
\hline I8 & 0.76 & 8 & Glass \& glassware \\
\hline I9 & 0.74 & I7 & Natural gas \\
\hline 20 & 0.73 & 6 & Wood industries \\
\hline 21 & 0.73 & I3 & Copper \& copper products \\
\hline 22 & 0.69 & 7 & Cement \\
\hline & I.0000 & Average of sectors \\
\hline
\end{tabular}

\section{Conclusion}

According to the forward linkage index and table ( $\mathrm{I}$ ), it is possible to say that for starting Iran's economic fast growth, sectors of glass and glassware, cement, mine, other mineral \& non-ferrous products, basic steel and iron mill products, paper $\&$ wood industries, chemical \& plastic industries, copper \& copper products, water and electricity in turn should be activated more than other sectors in order to fulfill the needs for intermediate products in the economy. The remained sectors have lower priority.

According to the table (2), relating backward linkage index, the sectors of foodstuff industries, aluminum, and other basic products of non-ferrous metals, copper and copper products, steel and iron mill products are able to increase the demand for intermediate products of other sectors more than the others.

The integrity index of table (3) shows that basic steel and iron mill products, copper and copper products, aluminum and other basic non-ferrous metals products, cement, paper, and wood industries, glass and glassware, other mineral non-ferrous products, chemical industries, and plastic are more integrated than the others relating both forward and backward linkages.

Intensity index of direct import according to the table (4) shows that more production percentages of industries of machinery and equipment, basic products of steel and iron mill, chemical industries and plastic are based on import.

Intensity index of intermediate import according to the table (5) shows that the share of intermediate import to the production of aluminum and other basic products of non-ferrous metals, chemical industries, and plastic, basic steel and iron mill products, machinery and equipment industries would be more than other sectors.

According to the multiplier coefficient of the table (6), aluminum and other basic products of non-ferrous metals, foodstuffs industries, basic products of steel and iron mill may have a higher multiplier effect in the economy. That is, the need for these sectors to intermediate products is higher than the other sectors, and in other words, it is possible to consider these sectors pioneer sectors and economy stimulator engine.

This idea would be confirmed by the dispersion index of the table (7). Aluminum and other basic products of non-ferrous metals, foodstuff industries, and basic products of steel and iron mill have more dispersion index in comparison to other sectors, and as a result, they more affect the growth of other sectors.

Sensitivity index in accordance with the table (8) shows that different sectors of chemical and plastic industries, agriculture, transportation services, warehouse keeping and communications, commercial services provide the highest amount of input for other sectors and lack of attention to these sectors may create a bottleneck for other sectors.

As mentioned earlier, the greatness of normal forward index (dispersion) and normal backward index (sensitivity) could be the result of linkages of one sector with few other sectors and with no total economy. The following indices designed to remove this shortage. Spread index for backward linkages in the table (9) shows that backward linkages of aluminum and other basic products of non-ferrous metals, textile and leather industries, copper and copper products are in linkage with few sectors.

Spread index for forward linkage in the table (I0) shows that forward linkage of aluminum and other basic products of non- 
ferrous metal is in relation with few other sectors, but building sector, cement, and other mineral non-ferrous products may have more linkage with lots of economic sectors to supply intermediate products.

Dispersion index after omission of import effect according to table (II) for foodstuff industries is higher than all other sectors and after that, copper and copper products, textile and leather industries, basic products of steel and iron mill, cement, wood industries, aluminum, and other basic products of non-ferrous metals have higher indices than the other sectors.

Also after omission of import effect, the sensitivity index in table (I2) shows that agriculture sectors, transportation services, warehouse keeping, and communications, commercial services are more sensitive from the point of view of production increase, and it is necessary to have more attention for supply of these sectors in order to prevent from any further problems in intermediate products of these sectors.

Considering the above calculations and the inter-relationships among economic sectors and without consideration of all other internal and external influent factors, we may consider the following scenarios for Iran's industrial strategy:

Scenario I: Foodstuffs industries sector is selected as the stimulator engine of the economy with an attitude of export promotion.

Scenario 2: Metals sectors (including aluminum and other basic products of non-ferrous metals, basic products of steel and iron mill) with export promotion and import substitution are selected as growth bases.

As it is obvious in scenario I, foodstuffs industries have the highest effect on the growth of other sectors. In case of increase of production along with foreign marketing of this sector, it is possible to be an optimist about the growth of the economy due to the growth effects of this sector. Development of this sector necessarily needs more motivation in the agriculture sector.

According to the information of the input-output table, about $\% 72$ of the raw materials of foodstuffs industries would be supplied by the agriculture sector. All services sectors in relation with this sector are obliged to supply about \% 2 of intermediate services for this sector and about $\% 9$ of intermediate products would be supplied by this sector itself and $\% 7$ by the other sectors. This is necessary to mention that according to some other calculations based on this table, the agriculture sector is of most job-creator sectors.

Table I3- Technologic classification of export

\begin{tabular}{ll}
\hline Classification & Example \\
\hline Primary products & $\begin{array}{l}\text { Fresh fruits, meat, rice, cocoa, tea, coffee, wood, coil, crude oil, and } \\
\text { gas }\end{array}$ \\
\hline $\begin{array}{l}\text { Source-based manufactured products } \\
\text { Products based upon agriculture/foresting }\end{array}$ & $\begin{array}{l}\text { Fruits/ready meat, drinks, wood products, vegetable oils } \\
\text { Gold concentrate, oil/plastic products, cement, decorative cutting }\end{array}$ \\
Products based upon other resources & stones, glass
\end{tabular}

Low technology
Textile/fashion

Other products with low technology
Factory textiles, clothes, head covers, footwear, leather products, travel goods

Vessels, simple metallic parts/ metallic item, furniture, jewelry, toys, plastic products 


\begin{tabular}{|c|c|}
\hline Automobile products & parts \\
\hline Processing industries with middle processing & $\begin{array}{l}\text { Superficial fibers, chemicals and paint, fertilizers, plastic, iron , } \\
\text { pipe/tube }\end{array}$ \\
\hline Engineering industries with middle processing & Engine, motor, industrial machine, pump, switch parts, ship, watch \\
\hline \multicolumn{2}{|l|}{ High technology } \\
\hline Electronic \& electric products & $\begin{array}{l}\text { Administrative equipment/ data processing, communication, T.V., } \\
\text { Transistor, Turbine, Electricity production equipment }\end{array}$ \\
\hline & Medicine, aerospace, optic tools/ measuring instruments, camera \\
\hline \multicolumn{2}{|l|}{ Other products with high technology } \\
\hline Other transactions & $\begin{array}{l}\text { Electricity, cinema film, publications, "special transactions", gold, } \\
\text { art, coins, domestic animals. }\end{array}$ \\
\hline
\end{tabular}

In option 2, and regarding the above-mentioned indices, it is possible to say that in case of selecting metals sector as the economy's stimulator engine, obviously, this sector is not pioneering as foodstuffs industries and is located after the latter, but regarding the need to import metals, we could be able to reach self-sufficiency. Of course, aluminum and other basic products of non-ferrous metals and copper and copper products are in relation with few sectors of the economy, and as a result, this scenario should be turned toward encouraging the sector of basic products of steel and iron mill in order to have more effects on economic growth.

It is necessary to note that both scenarios are categorized as resource-based manufacturing technology class from the viewpoint of export technologic classification. There are various methods for classification of products from the technologic point of view. One presented by Pavitt (1984) for clarification of industrial products as resource-based manufacturing, labor-intensive, scale intensive, science-based products. This classification, because of the complex nature of production processes and similarity of products is not practical. Proposed classification of OECD with more details on export goods from technologic point of view classifies the sectors as the table (13).

Scenario I would be classified in resource-based technology classification. This type of technology is simple and labor intensive, but some sectors of which need capital and large scale production and professions. The relative advantage of these products comes from the presence of necessary natural resources for these fields. Scenario 2 is classified in the second class of other products with low technology. More details of this class are explained at the end of the paper.

It is necessary to say that both scenarios have been regulated according to the analysis of the inter-sectoral relationships, and many domestic and foreign factors have been ignored. Therefore, it can draw only inter-industrial viewpoint, and by the way, these two scenarios are preliminary before any complete analysis of the other exogenous variables and phenomena.

\section{References}

Hatzichronoglou, T. (1996). "Globalization and Competitiveness: Relevant Indicators". Report prepared for the Organisation for Economic Co-operation and Development. OECD/GD (96) 43. Paris.

Pavitt, k. (I984) Sectoral patterns of technical change: towards a taxonomy and a theory, Research Policy, I3, $343-373$.

Lall, S. (2000) The technological structure and performance of developing country manufactured exports, I985-I998, QEH working paper series- QEHWPS44, June 2000. Queen Elizabeth House, University of Oxford, http://netec.mcc.ac.uk/WoPEc/data/Papers/qehqehwpsqehwps44.html

Nili, M (2003), Summary of industrial development strategy, Sharif University, Tegran, Iran

Bidabad, Bijan (2003), Territory management methodology in territory management of influence region of South Pars gas site, Genau Consulting Engineers, Oil Ministry, Iran, Tehran.

Bidabad, Bijan; Peyman Ghorbani (2002), Determining export markets for Iran's gas. Institute for energy studies, Iran, Tehran. Esfandiari, A.S. (I986), Determining key economic sectors based on forward and backward linkages, Plan and Budget Journal, No. 25, 26. pp.3-40. Iran, Tehran. 
Central Bank of Iran, (1997), Input-output table of Iran for the year I988.

Statistics Center of Iran, (1997), Input-output table of Iran for the year I99I.

\section{Copyrights}

Copyright for this article is retained by the author(s), with first publication rights granted to the journal. This is an open-access article distributed under the terms and conditions of the Creative Commons Attribution license (http://creativecommons.org/licenses/by/4.0/). 